\title{
IMDB, UN RECURSO DIGITAL PARA ALMACENAR LAS ESTRELLAS DE LA PANTALLA
}

\section{IMDB, A DIGITAL RESOURCE TO STORE THE STARS OF THE SCREEN}

\author{
Miguel Ángel Rivas Romero \\ (Departamento Historia del Arte, Universidad de Málaga, España) \\ mabusla@hotmail.com
}

Recibido el 06 de septiembre de 2017; aceptado el 20 de noviembre de 2017

\section{IMDB, UNA BASE DE DATOS PARA LA CULTURA POPULAR}

En uno de los primeros capítulos de la serie de televisión Lucifer (2016), fantasía policial desarrollada por Tom Kapinos para la FOX, su carismático protagonista, el mismísimo Diablo comenta, con su acento inglés impostado y haciendo gala de la fina la ironía y sarcasmo que caracteriza a este personaje creado para la aclamada serie de cómics The Sandmanı, que en la ciudad de Los Ángeles hasta los camareros tienen perfil en IMDb (Internet Movie Database).

Aunque en su adaptación televisiva, el personaje carece de la estética inspirada en David Bowie que luce en los cómics, sus comentarios siempre poseen más de una lectura. En nuestro caso, que un guionista televisivo haya incluido, en voz de un personaje de ficción, una referencia explícita a la base de datos cinematográfica on line, sitio web y catalogación social, que contiene información de todos los medios que integran las producciones audiovisuales; desde películas, programas de televisión, hasta videojuegos, así como de profesionales del sector, actores, directores, productores, localizaciones, datos de taquilla, etc., incluyendo incluso referencias a personajes ficticios, denota la importancia que para la cultura popular, no solo para la estadounidense, ha adquirido dicho recurso.

1 (Neil Gaiman, Sam Kieth, y Mike Dringenberg, 1988-1996), protagonizando su propio spin off, Lucifer (1999-2006, Mike Carey), 


\section{DE BASE DE DATOS A AGENTE DE CERTIFICACIÓN}

En la actualidad, la base de datos IMDb, inaugurada el 17 de octubre de 1990 y desarrollada por su creador Col Needham hasta que fue adquirida por Amazon.com en 1998, es un recurso digital, cuyo sitio web está programado en Pearl con sistema de bases de datos de desarrollo propio, mundialmente utilizado por investigadores, profesionales y por el gran público. Aunque la posibilidad de consultar y navegar por sus múltiples opciones está disponible sin petición de registro, sí es condición necesaria y gratuita para participar en las votaciones y calificaciones, discusiones, comentarios, así como si queremos acceder o crear listas de películas, catálogos, etc.

Desde que, en 1998, el fundador propietario y CEO de Amazon.com, Jeff Bezos, comprase IMDb para incorporarla como filial, la base de datos pasó de financiarse mediante patrocinio y publicidad a monetizarse mediante los anuncios del portal líder mundial de ventas online. Además, el 15 de enero de 2002 se añadió un servicio mediante pago por suscripción, con acceso a información más específica para profesionales, denominado IMDbPro.

Los contenidos de la web, no solo la información, sino también desde las noticias hasta las imágenes o los tráileres, están disponibles para los usuarios de teléfonos móviles y de tabletas, gracias a las aplicaciones gratuitas descargables desde Amazon apps, App Store y Google Play. Como no puede ser de otra forma, podemos seguir IMDb desde Facebook, Twitter e Instagram.

Además del equipo de profesionales que conforman la empresa, los usuarios registrados que lo deseen son los encargados de añadir, editar, validar, actualizar y corregir la información contenida en la base de datos, según unas normas publicadas en la web en la zona dedicada a los contributors. Así, IMDb es un buen ejemplo de cómo los repositorios que quieran continuar su expansión y crecimiento, una vez consumidos los fondos públicos o privados, y perdurar en el tiempo, deben integrar a los usuarios, que pasan de ser meros usuarios a participar en su mantenimiento de forma activa, mediante una política de gratificaciones no siempre económicas, como puede ser el acceso a la versión profesional de manera gratuita.

IMDb, siguiendo la línea de Amazon, ha comenzado este año 2017 a realizar sus producciones propias. The IMDb Show son una serie de programas con formato de Talk-Show 
televisivo. Desde el 16 de noviembre de 2017 se puede disfrutar en la web de episodios dedicados a promocionar y profundizar en los nuevos estrenos audiovisuales, contando con las aportaciones de directores, actores, celebrities, etc.

Aunque esta base de datos sea un recurso de gran valor para nuestros trabajos de investigación, no podemos eludir que la base de datos se ha convertido no en un mero repositorio sino en todo un agente de certificación de calidad. Si analizamos la lista de las mejores películas de todos los tiempos, quedaremos muy sorprendidos, mientras la brecha que separa el relato canónico sobre la Historia del Cine establecido hasta el momento por los especialistas y la publicada por la web aumenta cada día. En realidad, esto no debería resultarnos extraño, pues la modernidad, la postmodernidad y la hipermodernidad en la que nos encontramos, no son nada más y nada menos que aniquiladoras de los relatos hegemónicos. Es evidente que asistimos a la lucha encarnizada entre una visión del medio basada en la cinefilia y una nueva relación, la cinemanía.

IMDb es hija de su tiempo, de la sociedad digital, de la sociedad de la comunicación, fruto de una inédita relación entre el espectador -prosumidor sería el término más adecuadoy las producciones audiovisuales; luego su posicionamiento está totalmente sesgado a favor de aquellos que contribuyen a su supervivencia: la victoria de la cinemanía está garantizada. Valga este sencillo ejemplo, una de las consideradas obras maestras del séptimo arte, como en numerosas veces ha confesado Steven Spielberg es Centauros del Desierto (The Searchers, John Ford, 1956), pues los

65.000 usuarios que han puntuado este western consideran que merece un 8 , es decir, la misma calificación otorgada a la adaptación cinematográfica del antihéroe más gamberro de Marvel, Deadpool (Tim Miller, 2016), pero con 679.404 votos. Como bien comenta Laurent Jullier, a pesar de que el portal separa las críticas de los especialistas de las de los meros usuarios del portal, se continúa "manteniendo enormes diferencias entre la doxa cinefílica de los autores hollywoodienses (Julier, 2006: 77)]”.

Ante esta encrucijada podemos caer en la tentación de desestimar IMDb por su evidente sesgo generacional, pero nuestro pensamiento crítico no debe eclipsar nuestro compromiso como científicos, no debemos rechazar un recurso tan valioso pues somos humanistas digitales y nuestra misión es utilizar todos los recursos que esta sociedad digital nos proporciona -la 
indagación sobre la cultura artística a través de sistemas de representación digital y metodologías computacionales- para formular nuevas preguntas que generen un conocimiento significativo, que sea beneficioso para la comunidad científica, la cultura y la población en general.

No debemos tener vértigo ante la pérdida que supone el desmoronamiento de los relatos hegemónicos, pues de sus ruinas nacerán nuevos relatos, otros relatos, diversos, sin carácter universal, pero capaces de dar respuesta a la complejidad del hecho artístico, que incluya a los excluidos, a los marginados, a las periferias, a nosotros y a los otros, a los otros cines. Nuestras investigaciones serán la luz, y nosotros sus portadores: Lucifer.

\section{RECURSOS BIBLIOGRÁFICOS}

www.imdb.com Consultado (28/10/17).

JULLIER, L., ¿Qué es una buena película?, Barcelona, Paidós, 2006. 